\title{
THE USE OF INFORMATION SYSTEMS AS A WAY TO ENSURE INTERACTION BETWEEN SMALL AND BIG TOURISM ENTERPRISES
}

\author{
Svitlana Labunska ${ }^{1}$, Oleksandr Zyma², Serhii Sushchenko ${ }^{3}$ \\ ${ }^{1,2,3}$ Simon Kuznets Kharkiv National University of Economics, Kharkiv, Ukraine \\ e-mails: ${ }^{1}$ svetlana.lab@gmail.com, ${ }^{2}$ zima@ @neu.edu.ua, ${ }^{3}$ sergsushchenko@gmail.com
}

Received:20 November 2021 Accepted:27 December 2021 Online Published:05 January 2022

\begin{abstract}
The article is devoted to the information systems application in the sphere of small and big tourism enterprises interaction ensuring. The current role of information technologies due to their specific properties in the field of technical development of tourism as well as in the process tourism enterprises interaction ensuring is actualized. The advantages and features of the use of current information systems and technologies, in particular, global distribution systems, computer reservation systems, in the tourism enterprises business activity, which allow to ensure their effective interaction, are highlighted. The stages of the information technologies implementation in the tourism industry are determined. Taking into account the tourism industry specifics and the peculiarities of the information systems use in the tourism market business-entities activities, the authors determined the essence of the small and big tourism enterprises integrative interaction. The main global distribution systems used in the current tourism industry market are analyzed. The main actors controlling the global distribution systems' sector in the world are distincted. A comparative analysis of the main global distribution systems' conditions of use and maintenance is carried out. The main advantages of the global distribution systems, their use in the process of small and big tourism enterprises interaction ensuring are identified, and the prospects for their further development are shown.
\end{abstract}

Keywords: information systems, enterprise, interaction, tourism, GDS.

JEL classification: $L 83, L 86, Z 32, O 10$

Citation:

Labunska, Sv., Zyma, O., Sushchenko, S. (2022). The use of information systems as a way to ensure interaction between small and big tourism enterprises. Access to science, business, innovation in digital economy, ACCESS Press, 3(1): 1628. https://doi.org/10.46656/access.2022.3.1(2)

\section{INTRODUCTION}

The tourism industry market is becoming increasingly global. The world as a global space has been particularly influenced by the information technology dramatically development. For the currently society development, the role of information technology is strategically important, and its importance is growing rapidly. Information technologies make it possible to activate and efficiently use the information resources of the society. Effective use of information resources - scientific knowledge, discoveries, inventions, technologies, best practices - allow you to get significant savings in resources. 
In most developed countries, the level of business activity is increasingly determined by the processes of information generation, storage, processing and transferring. Therefore, business structures are forced to master and practically use information technologies corresponding to these processes. Information processes are an essential element of all complex industrial or social processes. The tourism industry is no exception. Information technologies have begun to play a significant role in the all tourism enterprises' business activities and interactions, regardless of their size and transaction volume. As a result, all enterprises, regardless of their size, product offering, and geography, have gone through major redesigning business processes. Now information technologies play an important role in the technical development of tourism, determined by a number of specific IT properties (efficiency and availability), as well as in the tourism enterprises' interaction ensuring processes. Thus, the use of information systems and IT in the process of small and big tourism enterprises interaction ensuring requires appropriate theoretical, methodological, and scientific support.

\section{BRIEF LITERATURE REVIEW}

The rapid development of information systems and technologies has fundamentally changed the tourism industry's functioning principles and architecture (Werthner \& Klein, 2005; Laverty, S., 2014). The Computer Reservations Systems (CRS) and Global Distribution Systems (GDS) introduction have transformed the operational practices in the tourism and in particulary in the airline industries dramatically (Buhalis, 2004; O’Connor, 1999; Emmer et al, 1993; eBusiness Watch, 2006; Constantinos et al, 2020).

The theoretical basis taking into account the small and big enterprises interaction aspects, its informational and economic ensuring developed in the scientific writings such as Porter, M. (1980), Varnaliy, Z. (2015), Sushchenko\&Trunina (2016), Todorova (2018A, 2019).

The issues of the tourism enterprises development, their informational support, and ensuring are receiving a lot of attention nowadays (Petrova et al, 2018; Lukjanova\&Odinokova, 2020; Chairoel et al, 2015; Marinov \&Todorova, 2020; Todorova, 2017; Todorova, 2018B). However, the issues of the information systems use as a way of small and big tourism enterprises interaction ensuring, their peculiarities essential research needs to.

\section{The purpose of the paper}

Despite the fact that information systems and ICT are currently a prerequisite for the tourism enterprises' stable development, many aspects of their use remain unrevealed. Insufficient knowledge of methodological and practical tools for the information systems and ICT implementation in the tourism enterprises operating activities are often the reasons that prevent companies from the higher level of development, and the use of small and big tourism enterprises interaction opportunities. The aim of the study is to critically analyze the benefits of the information systems and technologies' implementation in the tourism industry and to determine the possibilities of their use as a way of small and big tourism enterprises' interaction ensuring. 


\section{RESULTS and DISCUSSION}

Tourism business automation is closely related to the external business information collecting and analyzing system. These processes are complex and cover all aspects of a travel company's business activity. The external business information collecting systems provide managers with data on the tourism industry market functioning. Travel companies with a sufficiently high level of organization take additional measures to increase the relevance of external business information (various ratings, statistics, information about the travel situation) by encouraging travel agents and business partners.

Since environments do appear to be changeable and chaotic, it is necessary to ensure the adaptability of the tourism enterprise for its effective functioning. High reliability and ensuring adaptability are some of the fundamental principles of the tourism enterprises stable functioning. To do this, it is necessary to develop and implement complex information systems that concentrate a set of organizational, security, technical and other capabilities aimed at achieving a sufficient level of security and business efficiency.

In practice, tourism enterprises use various types of information technologies, namely: global distribution systems; electronic information systems; information management systems; mobile communication systems; services of the global computer network Internet.

The use of modern information technologies increases the safety and quality of travel services.

Currently, tourism uses the Global Distribution Systems (GDS), which provides fast and accurate booking of tickets for transport, hotel reservations, car rental, currency exchange, booking tickets for sports and cultural events, etc. Such systems allow booking all the main components of the tourism industry, i.e. they actually form a common information system that offers distribution networks for the entire tourism industry.

The development of the tourism business becomes impossible without modern information technologies' application, which provide (Shkola, 2003):

- integration and communication;

- $\quad$ service quality improvement;

- transfer of large amounts of information;

- increasing the speed of service and efficiency of business activities;

- the ability to take into account each client individual needs;

- effective feedback.

Information technology is a concentrated expression of scientific knowledge, information and practical experience, which makes it possible to rationally organize a particular business process. They allow you to save labor, energy or material resources needed to carry out this process. The time savings achieved through the use of any type of technology can be considered as a general criterion of efficiency. The need to save time 
is primarily aimed at technologies associated with the most massive information processes. Their optimization should save the most time due to their widespread and reusable use.

A truly revolutionary stage in the informatization of society is associated with an extraordinary increase in the use of global computer networks. The Internet is developing so rapidly that the number of users and the number of information resources almost doubles every year. More than 1 billion e-mails are transmitted over the network every second (Emmanuel et al, 2018).

Networked information technologies are an integral part of today's information society. Their objectives are as follows:

- ensuring the individual users' information exchange and making the possibility of the company's distributed information resources sharing;

- $\quad$ obtaining reference, documentary and other information from various specialized information funds.

The tourism business also uses Internet technologies for its growth and development. In recent years, thousands of independent sites of travel agencies, hotels, airlines, and dozens of travel services booking systems have appeared on the Internet. International and domestic tourism is a powerful trade services industry. The tourism industry is based on: tour operators and travel agents; hospitality; transport companies; tourism goods production and sale enterprises; advertising, information support, personnel training, as well as governing bodies. Also, other industries work for tourism, for which tourism services are not the main type of activity (culture, trade, etc.) (Emmanuel et al, 2018).

Tourism is an information-intensive activity. It is a liaison center that brings together different manufacturers in the tourism industry. Information flows, rather than goods, ensure links between tourism service providers; they go not only through dataflows, but also appear in the form of services and payments (Constantinos et al., 2020).

Tourism today is a field in which the processing, use and transfer of information is a vital component of daily activities. Consequently, tourism is almost entirely dependent on the relevant photo and video content, communications, and information transfer. Services such as hotel accommodations, car rentals, package tours, and airline tickets are implemented in today's global information environment through the use of information technology, namely computer reservation systems. It is through them that the interaction of all business structures - the tourism market subjects - is carried out.

One of the indicators for assessing the country's competitiveness in the field of tourism is "readiness for information and communication technologies" (ICT). This means growing rapidly, bringing in a large number of organizations, companies and countries, and reimagining their concept of "service delivery" to transform ongoing communication into experience. One of the parts of such readiness is the introduction of computer reservation systems at tourism enterprises. 
The first step in the computer reservation systems development was the installation of a terminal in most airlines offices, which significantly improved the quality and work of the airline personnel, without reducing the number of accepted booking requests from travel agents and individuals. The next step was to create flight bookings terminals in major travel agencies. Quickly assessing the effectiveness of new booking technologies, travel agents began to demand from airlines to significantly expand such systems functionality.

As a result, the software systems initially focused on a specific airline were merged into a system that served a group of airlines, providing information not only on the availability of a flight seats but also general information on flight details, fares, as well as information on related tourism industries - online booking experience for flights, rail, hotel rooms, car rental, taxis, and transfers (Constantinos et al., 2020).

There were several stages of the IT introduction into the tourism industry (GDS, 2021):

1. creating data - increasing the efficiency of the travel companies operating activities by automating processes based on the use of information;

2. the information management systems implementation and such information technologies development that would increase the management efficiency by improving the requirements for the information transfer organization;

3. the use of strategic information systems that could improve the firms' competitiveness. Various types of integrated networks have been implemented to improve the travel agencies operation activity as well as to establish links with external organizations;

4. the networking stage through which networks were connected at all levels: local, regional, and global. The main features of the phase are improving the IT efficiency, reducing the equipment's size and cost, increasing reliability, and organizing the interconnection of terminals located in different parts of the planet.

The use of modern information systems, namely, computer reservation systems, and GDS in the current tourism enterprises activity is one of the main elements of their integrative interaction ensuring. This will allow them to move along an ascending trajectory of development, use all available resources as efficiently as possible and interact with all tourism industry market business actors through related distribution channels (Fig. 1).

Integrity is one of the parametric categories of integration that determines the properties of the integrity of interacting subjects. Due to integrity there are relations of commonality of individual components in the process of their interaction, their corresponding wholeness is created. At the same time, the most important issue is not this property emergence, but its preservation in the process of further interaction development.

That is why factors that are system-forming for the subjects of interaction, such as their heterogeneity and opposite, are considered integrative. According to this study focus, integrity is the degree of unity, the holistic community of enterprises interacting with each other through the use of information systems and technologies. 


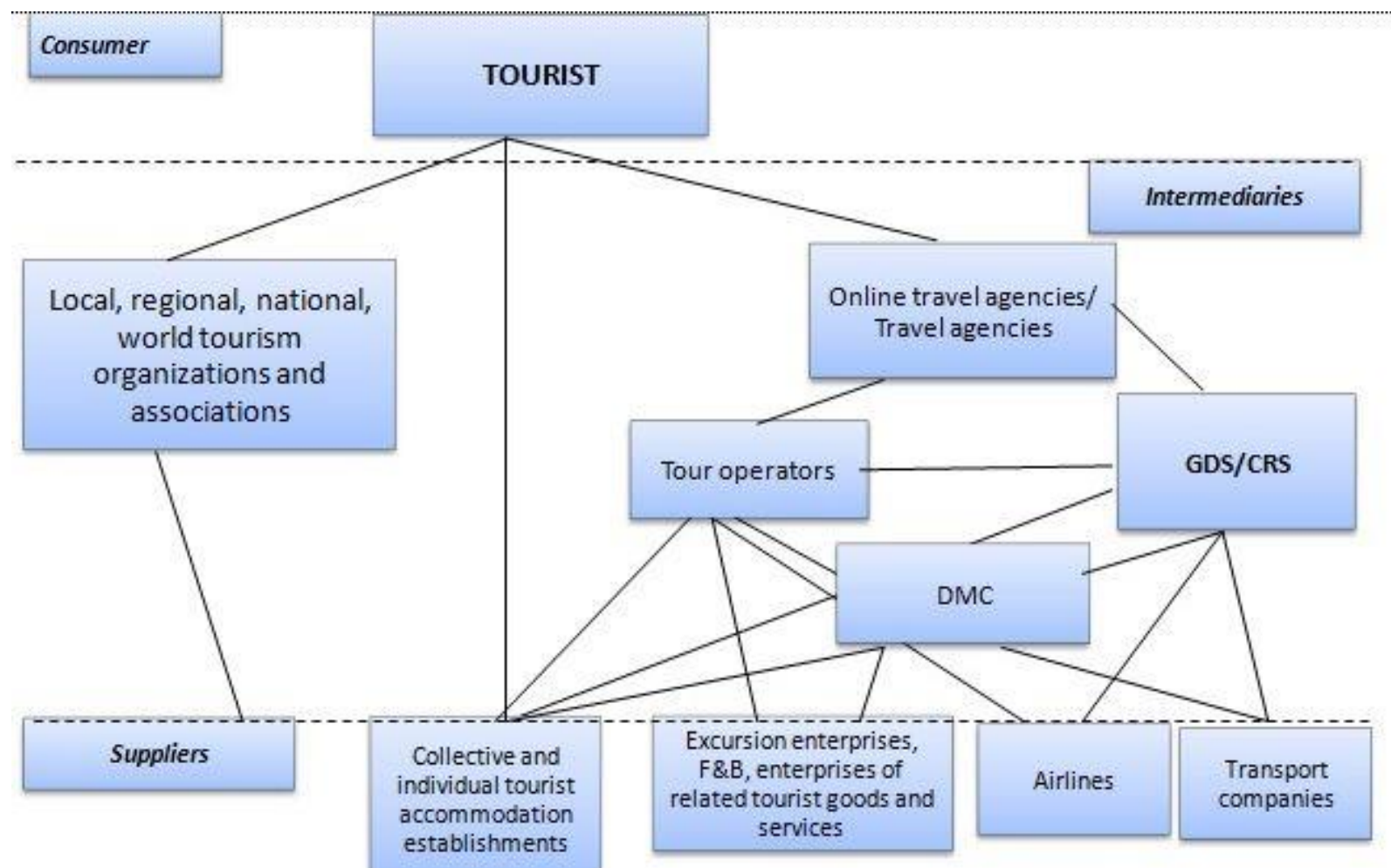

Figure 1. The tourism industry market subjects integrative interaction

The integrative interaction of small and big tourism enterprises should be understood as the organization and establishment of coherent links and joint actions of partner enterprises based on their potential's cooperative use in order to achieve common goals and economic interests with the formation of a holistic integrated system.

Travel services market is constantly evolving, e.g. tour operators creating new products by combining basic touristic services or their elements to serve the consumers. Travel agencies, as information intermediaries, provide consumers with valuable information and have the ability to book a travel product. Computer reservation systems and global distribution systems (CRS / GDS) cover flight reservation, in-flight and other relevant travel services. These systems provide the main connection with tour operators and travel agencies.

Actors on the right side of the field (Fig. 1) can be considered as an intermediate link between suppliers and consumers of tourism services. Role of the actors on the left side of the field is extremely important - they ensure all management, planning, administration, marketing and branding processes of travel destinations. They must represent the interests of all travel destination providers, but are not directly involved in the reservation process. 
Marketing and management organizations are often created by the state (government) at tourist destination level. These might be local, regional and national tourism organizations. Generating and using relevant information is a risk for a both sides of the tourism chain, i.e., for consumers and suppliers both.

Moreover, the aggreagation process of tourism services is information- intensive. The service must have clearly defined interfaces and all its aspect should be harmonized, meaning its pricing policies, terms of usage and distribution channels. This process is quite complex because the tourism product is diverse. The situation in the market of tourism services becomes more complicated as consumer behavior changes, as in other industries. As a result, the market becomes even more segmented, where each potential consumer might belong to multiple market segments at the same time (Stevenson, 2020).

The general trend in modern tourism is that tourists are looking for cheaper services, without reducing the requirements for their quality, and require more specific proposals for content and overall organization. In addition, tourists become even more mobile, but less loyal, as they compare many offers and prices. Theyy are going for more short-term trips and make subsequent decisions about them, which reduces the time between reservation and consuming (using) these services.

Great number of travel agents are relying on GDS to find the best services for their clients. And every year, more agents do realise that it's the best method to connect with airlines around the world. Now almost all tour operators represented in the Ukraine tourist services market have integrated GDS modules into their search engines. Its integration gave an opportunity to create unique service packages according to the consumer needs in the real-time mode. By using GDS, agents have access to the flight tariffs and availability, and can book seats for their clients. While the airline carefully fills in the flight report, GDS updates the search and shows the current information on the seats availability.

Many travel agents with corporate travel specialization use GDS to quickly and efficiently book seats for their clients. GDS can help airlines open new market segments to promote their products. In turn, through the GDS airlines explore new market segments of tourists that they previously could not reach.

Nowadays there are three main actors controlling the global distribution system sector - Amadeus, Saber and e-Travelport. They occupy more than $90 \%$ of the market, and the fourth participant has a share of only $6 \%$. This sector has some barriers to entry, as significant investment is needed to recreate GDS technologies (Emmanuel et al, 2018).

Amadeus Global Reservation System is the main project of the samenamed company in the field of travel services. The system is designed for reservation air tickets, cars, ferries, rail transport, hotels, cruises and insurance policies. The system is actively used by more than 400,000 professionals in the tourism industry worldwide. Today, more than 100,000 agent terminals are connected to Amadeus (TRAVELPORT, 2021).

One of the global CRSs, the Galileo system was founded in 1987 by KLM, British Airways, Swissair and Covia, they were later joined by Alitalia and Austrian Airlines. The company has about 3,000 employees and its headquarter is in Denver, Colorado, USA. Covia Airlines, which at the time had its own Apollo system, 
refocused its users on Galileo, and in 1993 the Galileo system merged with the Apollo system and became known as Galileo International (Constantinos et al., 2020).

The network services allows to provide tourists and travel agents with information about travel products and services, ticket reservation process, direct messaging and ordering additional services. More than 80 major hotel chains, such as Radisson, Hilton, Holidays, are connected to the network and allow travel agents to book hotel rooms (Constantinos et al., 2020).

Saber Travel Network is an organization that connects sellers and buyers of travel services through the world's largest trading platform - Saber Global Distribution System (GDS). More than 55,000 travel agencies and more than 400 airlines, 86,000 hotels, 25 car rental companies, 12 cruise companies are connected through Saber, which allows to develop the tourism industry (Constantinos et al., 2020).

Worldspan is an information system that provides reservations mainly for flights (487 airlines), but also in hotels (39 thousand hotels and 216 hotel chains), travel agencies, theaters and other cultural enterprises, car rental companies (rent 45 large companies). Worldspan also provides all the necessary background information related to travel and tourism. Currently, the system is used by more than 25,000 travel agencies around the world (Constantinos et al., 2020).

Table 1. Description of the main global distribution systems

\begin{tabular}{|c|c|c|c|c|}
\hline GDS Name & Amadeus & Galileo & Sabre & Worldspan \\
\hline Founders & $\begin{array}{c}\text { Lufthansa, Air } \\
\text { France, Iberia }\end{array}$ & $\begin{array}{c}\text { British Airways, } \\
\text { Swissair, Alitalia }\end{array}$ & $\begin{array}{c}\text { American } \\
\text { Airlines, IBM }\end{array}$ & $\begin{array}{c}\text { Delta Airlines, } \\
\text { Northwest } \\
\text { Airlines }\end{array}$ \\
\hline Year of foundation & 1987 & 1987 & 1964 & 1991 \\
\hline $\begin{array}{c}\text { Number of } \\
\text { connected airlines }\end{array}$ & 489 & 470 & 420 & 365 \\
\hline $\begin{array}{c}\text { Number of } \\
\text { connected hotels }\end{array}$ & 51794 & 56000 & 40000 & 26000 \\
\hline $\begin{array}{c}\text { Number of car } \\
\text { rental companies }\end{array}$ & 48 & 24 & 50 & 40 \\
\hline $\begin{array}{c}\text { Number of } \\
\text { terminals }\end{array}$ & 100166 & 119400 & 122891 & 47950 \\
\hline
\end{tabular}

Source: created by the author on the basis of (Emmanuel et al, 2018)

Therefore, GDS is a computer web service that provides pricing, real-time services availability, centralized data display with reservation functions for the global travel industry in a single process. Amadeus, Saber, Galileo and Worldspan are the main four providers of GDS in the tourism industry, which help travel agents increase their travel operations. Each of these systems has certain technical features and special conditions of interaction with tourism enterprises. 
Among Ukrainian tourism companies, the most common are such GDS as Amadeus and Saber, as they allow the most efficient use of their opportunities to work in the European and American tourism markets. Table 2 shows a comparison of the terms of usage and integration of both global distribution systems.

Table 2. GDS terms of service comparison

\begin{tabular}{|c|c|c|}
\hline Paragraph & Amadeus & SABRE \\
\hline $\begin{array}{l}\text { Air segments sale rate for free } \\
\text { system usage }\end{array}$ & $\begin{array}{l}75 \text { segments per terminal per } \\
\text { month }\end{array}$ & $\begin{array}{l}30 \text { segments per terminal per } \\
\text { month }\end{array}$ \\
\hline $\begin{array}{c}\text { Service fee for the sale of } \\
\text { Content Rail Ukraine by system }\end{array}$ & $10,44 \mathrm{UAH}$ to the cost & $5 \mathrm{UAH}$ to the cost \\
\hline $\begin{array}{c}\text { Incentive per each flight } \\
\text { segment }\end{array}$ & None & $\begin{array}{c}1.50-2.00 \text { USD per each } \\
\text { segment }\end{array}$ \\
\hline Bonus program for agents & $\begin{array}{c}\text { Equivalent of the points: } \\
5 \text { points per air segment } \\
5 \text { points per train segment } \\
10 \text { points per hotel segment } \\
10 \text { points per car rent segment } \\
10 \text { points per insurance segment } \\
50 \text { UAH certificate } \\
=\text { in average } 165 \text { points }\end{array}$ & $\begin{array}{c}1 \text { segment }=5 \text { points }=5 \mathrm{UAH} \\
10 \text { segments }=50 \mathrm{UAH} \\
\text { certificate } \\
\text { Certificate can be used in the } \\
\text { large retail chains in Ukraine, } \\
\text { such as Rozetka, Novus, etc. }\end{array}$ \\
\hline Support center & $\begin{array}{c}\text { Amadeus Service Hub 24/7 } \\
\text { support }\end{array}$ & $\begin{array}{c}\text { Central SABRE Support 24/7 } \\
\text { free online and call center } \\
\text { support }\end{array}$ \\
\hline
\end{tabular}

Source: created by the authors

Regarding economic component, the Saber system encourages cooperation by earning additional profit in the form of incentives for each air segment sold. GDS is and will remain the most important distribution channel for airlines, hotels and car rental companies. However, the Internet also allows GDS companies, eticket providers and even traditional travel agents to host websites that have access to their connections (APIs) and provide services that were previously offered offline (Fig. 2).

The main advantages of global distribution systems are as follows (Stevenson, 2020):

1. The use of the global distribution system indicates an increase rate in the number of corporate customers and tourists.

2. GDS is very effective method to attract foreign travelers. This is the reason why the use of GDS among travel agents is growing exponentially every year.

3. OTA (online travel agents) have significantly improved the experience and convenience of consumer shopping while traveling and increased pricing transparency.

4. GDSs include business models of a retail travel agencies and OTA.

5. GDS allows travel agents to make their travel services available to consumers around the world, where 
they would not otherwise be able to effectively promote their services through direct marketing efforts.

6. Reservation through GDS is safe and secure option, thus complies with most of the corporate clients needs.

7. Travel agents are able to easily get a global platform for their business with a strong impact on the market.

8. The global distribution system is the basis for finding corporate customers around the world.

9. GDS gives an opportunity to check the actual service availability in real time. Thereby managers can view changes in tariffs and easily change price or make special offers. Agents can instantly review all changes and are able to give customers relevant offers.

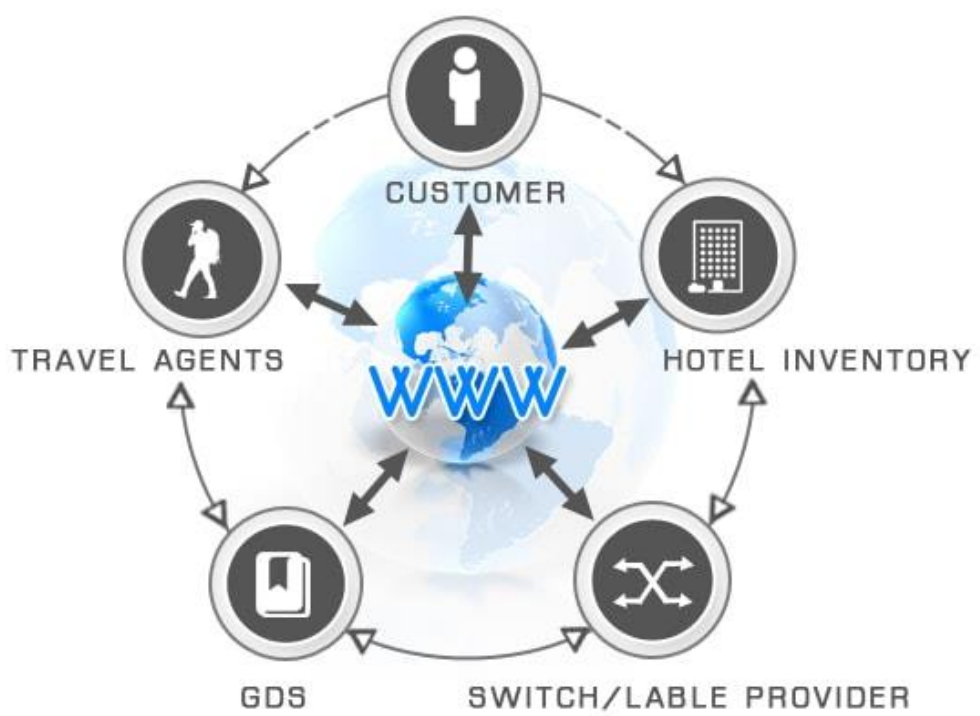

Figure 2. Internet and GDS connection scheme with intermediaries and end customer (GDS, 2021).

Meanwhile, the development of mobile technology and spread of smartphones with 4G and 5G connection support are pushing use of mobile services in the travel business and ensure the interaction of its actors. Currently, mobile websites and applications are able to connect to the API to receive and update data as fast as their desktop versions. For this reason, travel technology providers have focused on developing services to book flights directly from smartphones.

Launched in 2004, the KAYAK iOS app is considered to be the first example of a mobile travel app. Since 2010, mobile websites and applications have become the standard in the travel industry. Soon, all other metasearch travel systems, OTA, airlines reservation tools have created their own mobile applications. Besides, passengers can now use their smartphones as an electronic ticket by scanning the barcode, which became today's standard. 
In 2019, online booking has undergone several minor improvements, which are usually related to overall technical progress. Online payment systems have become much more secure, providing fast processing or even transactions with cryptocurrencies.

The popularization of mobile apps allows travellers to plan a week-long trip in minutes, book tickets, hotel rooms and rent a car in just a few taps. The distribution system is gradually changing every year. An example of recent changes is the New Distribution Capabilities (NDC), which have been in place since 2012. Although it did not bring major changes, it forced GDS to introduce more modern data transmission channels to distribute supplementary products to consumers. In consequence, more online booking platforms and OTA have gained access to rich content, giving customers more opportunities.

\section{CONCLUSION}

The growth of the tourism sector subsequently affects the transport and communications sectors, which due to the growing demand for travel have become one of the main consumers of innovation and information technology, namely: computer reservation systems, global distribution systems, electronic information and communication systems. There was a clear increase in the number of airlines, transport companies, as well as the growth of air traffic. It has led to the creation and implementation of computer reservation systems, which have become the main tool for tickets reservation. Global distribution systems provide an opportunity to significantly improve the quality of customer service by reducing reservation time, refining the quality of service and overall efficiency of airline staff.

In general, the use of information technologies, modern information systems, GDS in particular, allows to ensure interaction of small and large tourism enterprises. Furthermore, it allows:

- customize the experience of clients of travel agencies and travel service providers;

- involve the main providers of tourist services in a reliable and efficient global commercial network;

- use modern management and marketing tools in the activities of tourism enterprises, which allow to increase competitiveness and ensure sustainable development;

- provide an opportunity for airlnes to use information systems in their offices to improve interaction with agents and partners;

- provide global services through unified e-commerce systems in the tourism industry, as well as provide integrative relationships with key players in the tourism business.

\section{Conflict of interests}

The authors declare no conflict of interest. 


\section{References}

Buhalis, D. (2004). eAirlines: Strategic and tactical use of ICTS in the Airline Industry. Information \& Management, 41(7), 805-825.

Chairoel, Lucy \& Widyarto, Setyawan \& Pujani, Vera. (2015). ICT adoption in affecting organizational performance among Indonesian SMEs. The International Technology Management Review. Vol. 5. 82-93. 10.2991/itmr.2015.5.2.3.

Constantinos Halkiopoulos, Hera Antonopoulou, Dimitrios Papadopoulos, Ioanna Giannoukou, \& Evgenia Gkintoni. (2020). Online reservation systems in e-Business: Analyzing decision making in e-Tourism. Journal of Tourism, Heritage \& Services Marketing, 6(1), 9-16. https://doi.org/10.5281/zenodo.3603312

eBusiness W@tch, (2006), ICT and e-Business in the Tourism Industry, Sector Impact Study No. 08 / 2006, European Commission, http://www.ebusiness-watch.org/resources/tourism/SR08-2006_Tourism.pdf

Emmanuel, A.A., Oluwafunmilayo, O.O., Mobolaji, O.A., Abioye, A., \& Adedoyin, O.O. (2018). Perception of Travel Agents Towards Amadeus and Galileo Global Distribution System. Canadian Social Science, 14, 17-30.

Emmer, R.M., Tauck, C., Wilkinson, S., \& Moore, R.G. (1993). Marketing hotels using global distribution systems. Cornell Hotel and Restaurant Administration Quarterly, 34(6), 80-89.

Global Distribution Systems / VIPSERVICE Partners, 2021. URL: https://www.vipservice.ru/En/partners/partners2.php.

Laverty, S. (2014). Impact of technology on the travel agency business, Houston Cronical. http://smallbusiness.chron.com/ impact technology-travel-agency-business-57750.

Lukjanova, L., Odinokova, T. (2020). Innovations as the main challenge in the field of health tourism in Latvia. Access to science, business, innovation in digital economy, ACCESS Press, 1(1): 39-52. DOI: https://doi.org/10.46656/access.2020.1.1(3)

Marinov, M., Todorova, L. (2020). Effects of the COVID - 19 Impact on the Tourism Sector in Bulgaria. Izvestia Journal of the Union of Scientists - Varna. Economic Sciences Series, 9(2), pp.68- 75. DOI: https://doi.org/10.36997/IJUSV$\underline{\mathrm{ESS} / 2020.9 .2 .68}$

O’Connor, P. (1999). Electronic Information Distribution in Tourism \& Hospitality, Wallingford:CAB.

Petrova, M., Dekhtyar, N., Klok, O., \& Loseva, O. (2018). Regional tourism infrastructure development in the state strategies. Problems and Perspectives in Management, volume 16(4), $259-274$. https://doi.org/10.21511/ppm.16(4).2018.22

Porter, M. E. Competitive Strategy: Techniques for Analyzing Industries and Competitors. New York: Free Press, 1980. (Republished with a new introduction, 1998.)

Shkola, I. (2003). Management of tourism industry (662 p.). Chernivtsy: ChTEI KNTEU.

Stevenson (2020). Why is GDS important to the travel industry? URL: https://medium.com/@ stevenson14789632/whyis-gds-important-to-the-travel-industry-551ed4bffc2

Todorova, L. (2018A). Possibilities for Bulgaria's development as a multi-aspect tourist destination. Quantitative and qualitative analysis in economics: Proceedings of the International Scientific Conference - Nis, October 18, 2018, p. 137-142, ISBN: 978-86-6139-170-5

Todorova, L. (2018B). The development of cultural tourism in Bulgaria-a springboard for increasing the attractiveness of the destination. Izvestia Journal of the Union of Scientists - Varna. Economic Sciences Series, 7(1), pp.121-127.

Todorova, L. (2017). Challenges to entrepreneurs in the tourist sector in Velingrad municipality. Proceeding of University of Ruse, 2017, vol. 56, book 5.1., p.31-36

Todorova, L. (2019). The state and opportunities for the development of tourism in the municipalities in the lower Danube river. Proceedings of the International scientific and practical conference "Bulgaria of regions'2019", p.333-339

TRAVELPORT, 2021. URL: https://travelport.ua/.

Varnaliy Z., Pugach, A. (2015). Forming the priority guidelines for providing the state есопотіс seсurity / Економіка $\mathrm{i}$ регіон. - 2015. - № 5. - C. 3-9: http://nbuv.gov.ua/UJRN/econrig_2015_5_3.

Werthner, H., \& Klein, S. (2005). ICT-enabled innovation in travel and tourism. Innovation and product development in tourism (pp.71-84). Berlin: Erich Schmidt Verlag. 
About the authors

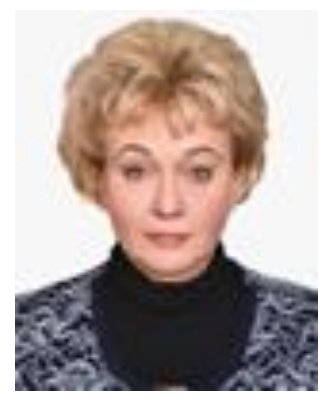

\section{Svitlana LABUNSKA}

Dr.Sc. (Economics), Professor, Simon Kuznets Kharkiv National University of Economics, Kharkiv, Ukraine. Scientific interests: innovation activities cost management in the system of economic security of the enterprise financial and economic activities.

ORCID ID: https://orcid.org/0000-0002-0989-6806

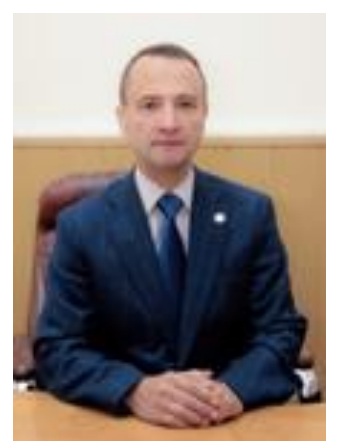

\section{Oleksandr ZYMA}

$\mathrm{PhD}$ (Economics), Associated Professor, Simon Kuznets Kharkiv National University of Economics, Kharkiv, Ukraine. Scientific interests: tourism and hospitality, economics and management, international business.

ORCID ID: https://orcid.org/0000-0001-6917-0858

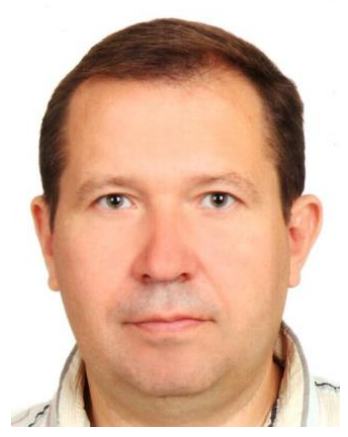

\section{Serhii SUSHCHENKO}

PhD student, Simon Kuznets Kharkiv National University of Economics, Kharkiv, Ukraine. Scientific interests: economics and management, tourism and hospitality.

ORCID ID: https://orcid.org/0000-0003-2990-9683

\section{Copyright (C) 2020 by author(s) and ACCESS Publishing Press This work is licensed under the Creative} Commons Attribution International License (CC BY) 